\title{
Studies on imidazo[2,1-b][1,3]benzothiazole derivatives as new radiosensitizers
}

\author{
Krishnakishore Majalakere ${ }^{1} \cdot$ Sarojini Balladka Kunhana ${ }^{1} \cdot$ Shama Rao $^{2} \cdot$ Bhuvanesh Sukhlal Kalal $^{3}$. \\ Narayana Badiadka ${ }^{4}$. Ganesh Sanjeev ${ }^{5}$. Bantwal Shivaram Holla ${ }^{6}$
}

Received: 1 July 2020 / Accepted: 15 October 2020 / Published online: 27 October 2020

(c) Springer Nature Switzerland AG 2020

\begin{abstract}
The synthesis and characterization of potent 7-substituted-2-(4-substitutedphenyl)imidazo[2,1-b][1,3]benzothiazoles as effective radiosensitizers and anticarcinogenic compound is reported. The activity is determined against human liver cancer Hep G2 cell line, two parental melanoma cell lines (human melanoma cell line, A375C and mouse melanoma cell line, A375C). The compounds 7-sulfonamide-2-(4-fluorophenyl)imidazo[2,1-b][1,3]benzothiazole $\left(\mathbf{3 f}, I C_{50}=0.097 \mu \mathrm{M}\right)$ and 7-sulfonamide-2-(4-methylphenyl)imidazo[2,1-b][1,3]benzothiazole $\left(\mathbf{3 g}, I C_{50}=0.114 \mu \mathrm{M}\right)$ exhibited considerable in vitro anticancer activity against Hep G2 cell line while 7-bromo-2-(4-fluorophenyl)imidazo[2,1-b][1,3]benzothiazole showed effectiveness against both parental melanoma cell lines ( $3 c, I C_{50}=0.04$ and $0.052 \mu \mathrm{M}$ ). Further the active molecules $\mathbf{3 f}, \mathbf{3 g}$ and $\mathbf{3 h}$ are tested for radiosensitizing activity over Hep G2 cell line at $4 \mathrm{~Gy}$, with the comet formed at $0.054 \mu \mathrm{M}$. Similarly, $3 \mathbf{c}$ tested against two parental melanoma cell lines, it has proven to be more potent when combined with $2 \mathrm{~Gy}$ $\Upsilon$-radiation. The present study reveals that presence of sulfonamide in combination with methoxy substitution enhanced DNA fragmentation and there by acting as effective derivative for Hepatocellular carcinoma.
\end{abstract}

Keywords 7-Substituted-2-(4-substitutedphenyl)imidazo[2,1-b][1,3]benzothiazole · Anticancer · Hep G2 · Melanoma cell lines · Radiosensitizing

\section{Introduction}

Of late many drugs put in clinical practice have proven ineffective in combating the target cancer due to various factors that include multidrug resistance and adverse drug reactions. Hence, there always exists quite a large demand for novel anticancer drugs which instigates an interest among scientists for the development of new natural products or synthetic compounds as potent candidates for drug development.

Radiotherapy is one of the most advanced and highly evolved areas in anticancer therapy for most of the cancers. This therapy works by directing high energy ionizing radiation towards cancer cells, thereby causing genetic changes triggering cell death [1]. In most of the cases radiation therapy loses its effectiveness due to hypoxic nature of cancer cells [2]. To overcome this, radiosensitization of

Electronic supplementary material The online version of this article (https://doi.org/10.1007/s42452-020-03726-7) contains supplementary material, which is available to authorized users.

Sarojini Balladka Kunhana, bksaroj35@gmail.com | 'Department of Industrial Chemistry, Mangalore University, Mangalagangothri, Karnataka 574199, India. ${ }^{2}$ Centre for Stem Cell Research and Regenerative Medicine, Justice K.S. Hegde Medical Academy, Deralakatte, Mangaluru, Karnataka 575017, India. ${ }^{3}$ Department of Biochemistry, Yenepoya Medical College, Yenepoya (Deemed to be University), Mangaluru, Karnataka 575018, India. ${ }^{4}$ Department of Chemistry, Mangalore University, Mangalagangothri, Karnataka 574199, India. ${ }^{5}$ Microtron Centre, Department of Physics, Mangalore University, Mangalagangothri, Karnataka 574199, India. ${ }^{6}$ Department of Postgraduate Studies in Chemistry, Sri Dhramasthala Manjunatheshwara College, Ujire, Karnataka 574240, India. 
tumor cells has done by using certain agents known as 'radiosensitizers'. These compounds help to sensitize the tumor cells towards radiation by inducing free radical generation, denaturing macromolecules and inhibiting DNA repair mechanisms thus leading to cell death [2].

A broad spectrum of anticancer activities exhibited by sulfonamide hybrids with minimum side effect and better drug resistance-reversal ability had made them as an attractive pharmacophores. The metallo enzymes which were found in eukaryotic and many prokaryotic cells were known as carbonic anhydrases (CAs, EC 4.2.1.1) play a role in catalyzing reversible hydration/dehydration of $\mathrm{CO}_{2} /$ $\mathrm{HCO}_{3}$. Sulfonamide derivatives of heterocycles had exhibited strong $C A$ inhibiting activity than other derivatives were documented. Previous reports had shown that compounds with thiophene-2-sulfonamide cores were found to be 40 times more active than benzene sulfonamide derivatives to inhibit carbonic anhydrases [3, 4]. A radio/ chemosensitizing sulfonamide/sulfamide/sulfamate derivatives of nitroimidazoles act as CA IX inhibitors targeting the tumor-associated carbonic anhydrase (CA) isoforms IX and XII. They exhibited potency on hypoxia-induced extracellular acidosis in HT-29 and HeLa cell lines. The sulphonamide derivatives of these series in combination with dioxorubicin inhibited hypoxic tumors over expressing extracellular CA isozymes. The LEAD compounds for anticancer activity such as SLC-0111 [5], Indisulam [6] were being tested under the anticancer clinical trials. Fusion of thiazole and imidazole pharmacophores into a single molecular frame work might enhance the therapeutic potential of the individual scaffolds. The Mannich bases of 2-arylimidazo[2,1-b]benzothiazole derivatives were proven to be potential killers of cancer cells with $\mathrm{IC}_{50}$ ranging from 2.8 to $8 \mathrm{mM}$ [7]. As a consequence it was aspired to synthesize a series of thiazole incorporating imidiazole moieties which were previously reported as antimicrobial agents [8].

Herein, it is attempted to analyze these scaffolds for their in vitro antiproliferative and radiosensitizing activities. A synergistic effect of anticancer and radiosensitization properties, probably would prove to be more beneficial based on the advantage of pharmaco-economic point of view.

\section{Experimental}

The analytical grade chemicals were purchased from Spectrochem Pvt. Ltd. Mumbai (India) and were used for reaction. The Merck silica gel 60 F254 aluminum sheets (Merck, Germany) were used for thin-layer chromatography to monitor reaction progress with ethyl acetate:hexane (3:7) as eluent. Digital melting point/boiling point apparatus (EQ 730) was used to determine uncorrected melting point in a capillary tube. Bruker Avance FT-NMR spectrophotometer was used for recording ${ }^{1} \mathrm{H}$-NMR and ${ }^{13} \mathrm{C}$-NMR at room temperature with TMS as internal standard.

\subsection{Synthesis of 6-substituted-1,3-benzothia- zol-2-amine}

The synthesis of the compound 6-substituted-1,3-benzothiazol-2-amine was carried out according to the procedure reported in the literature (Scheme 1) [9].

\subsection{Synthesis of 7-substituted-2-(4-substitutedphe- nyl)imidazo[2,1-b][1,3]benzothiazoles}

To a stirring solution of 6-substituted-1,3-benzothiazol2-amine [ $0.00256 \mathrm{~mol}]$ in $10 \mathrm{ml}$ methanol was added of 4-substituted phenacyl bromides [0.00282 mol] and subjected to reflux for 6-8 h. The precipitated solid was filtered, washed with cold methanol and dried. The products were checked for their purity with TLC and found to be pure (Scheme 2).

\subsection{In vitro anticancer activity}

\subsubsection{3-(4,5-Dimethylthiazol-2-yl)-2,5-diphenyltetrazolium bromide (MTT) assay}

The anticancer activity screening of compounds $\mathbf{3 a}-\mathbf{h}$ was performed in HepG2 cell line, two parental melanoma cell line (human melanoma cell line, A375C and mouse melanoma cell line, $A 375 C$ ) and two drug resistant sublines (B16F10R and A375R) [10]. Cells cultured in Dulbecco's modified Eagle's medium (DMEM) supplemented with $10 \%$ heat-inactivated fetal bovine serum, $2 \mathrm{mmol} / \mathrm{l}$ glutamine, $1 \%$ antibiotics solution $(100 \mathrm{U} / \mathrm{ml}$ penicillin $\mathrm{G}$ and $100 \mathrm{mg} / \mathrm{ml}$ streptomycin). Cells were grown in $25 \mathrm{~cm}^{2}$ tissue culture flasks and maintained at $37^{\circ} \mathrm{C}$ in a humidified incubator with $5 \% \mathrm{CO}_{2}$. The Hep $\mathrm{G} 2$ cells were seeded in 96 well plates with density of 10,000 cells/well. The proper adhesion of the cells where obtained by incubating for $24 \mathrm{~h}$ in $100 \mu \mathrm{l}$ DMEM complete medium. Varied concentrations of studied compounds were dissolved in 10\% DMSO

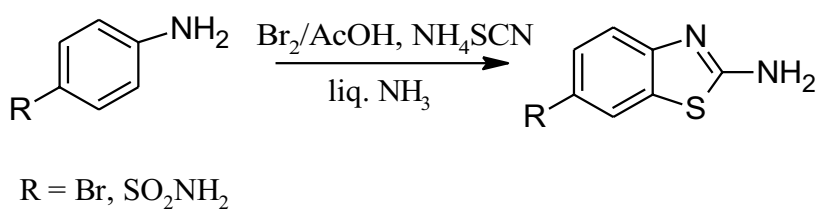

Scheme 1 Synthesis of benzothiazole amine 


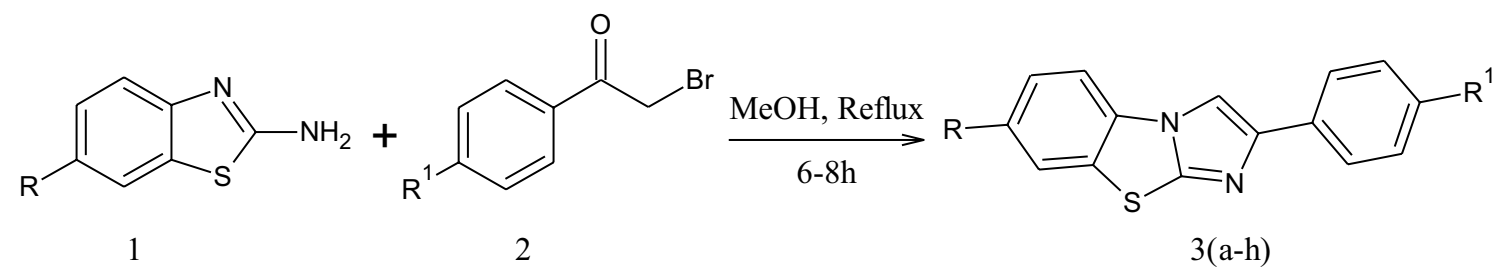

$$
\begin{aligned}
& \text { R - Br, } \mathrm{SO}_{2} \mathrm{NH}_{2} \\
& \mathrm{R}^{1}-\mathrm{OCH}_{3}, \mathrm{~F}, \mathrm{CH}_{3}, \mathrm{NO}_{2}
\end{aligned}
$$

Scheme 2 Synthesis of target compounds (3a-h)

and were put onto cells. Further incubated for $24 \mathrm{~h}$ and $0.5 \mathrm{mg} / \mathrm{ml}$ MTT solution was added. On incubation for $4 \mathrm{~h}$ the purple colored formazane crystals formed were dissolved in DMSO and OD recorded at $570 \mathrm{~nm}$.

\subsubsection{Radiation sensitization experiment}

First, cell lines were irradiated with different doses of radiation and among them; a dose $2 \mathrm{~Gy}$ radiation was considered optimum for radiation sensitization experiments. Cells were seeded in tissue culture flask (Tarsons) and allowed to stand overnight for adherence. Next day, these cell lines were treated with drugs $\left(\mathrm{IC}_{25}\right.$ dose) in media and further incubated for $24 \mathrm{~h}$. After incubation, cell culture was irradiated with gamma radiation at the Centre for Application of Radioisotopes and Radiation Technology (CARRT), Mangalore University, India. Upon irradiation, the cells were seeded in triplicates into 96-well plate and incubated for $24 \mathrm{~h}$. The MTT assay was performed for calculation of cell viability percentage. The unirradiated cultured cells were used as controls.

\subsubsection{Comet assay}

The standard radiation dosage was determined by performing comet assay for Hep G2 cell lines. The cells were exposed from 2 to $10 \mathrm{~Gy}$ radiation dosage and the formed comet was observed under fluorescent microscope. It was found that a dose of $4 \mathrm{~Gy}$ was effective to rupture the cells, hence the comet assay was performed with $4 \mathrm{~Gy}$ radiation dosage. About 10,000 cells/vial were placed in a vial and treated with $20 \mu \mathrm{ldrug}(1 \mathrm{mg} / \mathrm{ml})$ solution which was exposed to $4 \mathrm{~Gy} \Upsilon$-radiation. After $24 \mathrm{~h}$ of incubation Trypan blue staining was used to check the viability of cells. Then glass slides pre-coated with agarose were spread with the cells and used for alkaline comet assay. The lysis solution [10 mM Tris, 100 mM EDTA, $2.5 \mathrm{M} \mathrm{NaCl}, 10 \%$ DMSO, 1\% Triton X-100 (pH 10)] was used for lysing the cells for $3 \mathrm{~h}$. The solution was further kept for 20 min at $4{ }^{\circ} \mathrm{C}$ in alkaline conditions ( $300 \mathrm{mM} \mathrm{NaOH}, 1 \mathrm{mM} \mathrm{EDTA}, \mathrm{pH} \geq 13$ ) for DNA unwinding. The electrophoresis was performed at $4^{\circ} \mathrm{C}$ for $20 \mathrm{~min}$ under an electrical current of $400 \mathrm{~mA}(25 \mathrm{~V})$. On neutralization with Tris $\mathrm{HCl}(0.4 \mathrm{M})$, dehydration using $70 \%$ ethanol and staining with ethidium bromide $(10 \mu \mathrm{g} /$ $\mathrm{ml}$ ) the slides were analyzed on fluorescence microscope (400× magnification, Eclipse 50i, Nikon, Kanagawa, Tokyo).

\section{Results and discussion}

\subsection{Chemistry and spectral characterization}

The 7-substituted-2-(4-substitutedphenyl)imidazo[2,1-b] $[1,3]$ benzothiazole derivatives $(\mathbf{3} \mathbf{a}-\mathbf{h})$ were synthesized from 6-substituted-1,3-benzothiazol-2-amine was confirmed by their spectroscopic characterizations. The FTIR spectral details indicated the formation of the target molecules. One of the representative compound $\mathbf{3 a}$ (7-bromo2-(4-methoxyphenyl)imidazo[2,1-b]benzothiazole) absorbed characteristic frequencies $1683 \mathrm{~cm}^{-1}(-\mathrm{C}=\mathrm{N}), 1246 \mathrm{~cm}^{-1}$ $(-\mathrm{C}-\mathrm{O}), 694 \mathrm{~cm}^{-1}(-\mathrm{C}-\mathrm{S}), 518 \mathrm{~cm}^{-1}(-\mathrm{C}-\mathrm{Br})$ the IR active groups present in the molecule. The bending and stretching vibrational frequencies due to amine group present in the parent molecule at $3246 \mathrm{~cm}^{-1}$ were absent. The ${ }^{1} \mathrm{H}-\mathrm{NMR}$ of $3 \mathrm{a}$ showed singlet peak at $\delta 3.79 \mathrm{ppm}$ corresponded to three methoxy protons substituted on phenyl ring. A doublet centered at $\delta 7.01 \mathrm{ppm}$ integrating for two protons with coupling constant $J=8.0 \mathrm{~Hz}$ could be assigned for the meta protons of phenyl ring and another doublet seen at $\delta 7.78 \mathrm{ppm}(\mathrm{J}=8.0 \mathrm{~Hz})$ could be assigned for ortho protons of phenyl ring. Further, the signals appeared for thiazole fused phenyl ring protons as two singlets and one doublet. The ortho and one of the meta protons of bromophenyl ring appeared as singlets at $\delta 7.91 \mathrm{ppm}$ and a doublet at $\delta 7.96 \mathrm{ppm}(\mathrm{J}=8 \mathrm{~Hz})$ integrating for one proton each respectively. Another singlet appeared at $\delta 8.34 \mathrm{ppm}$ could be assigned for the other meta proton of the bromophenyl ring. The signal 
resonated at $\delta 8.65 \mathrm{ppm}$ due to imidazole ring proton. Formation of the final product further confirmed by the absence of signals at $\delta 8.14 \mathrm{ppm}$ for $-\mathrm{NH}_{2}$ proton of precursor. In the ${ }^{13} \mathrm{C}$ NMR spectrum, signal obtained at $\delta$ $55.6 \mathrm{ppm}$ could be assigned to methoxy group carbon and a downfield signal appeared at $\delta 193.4 \mathrm{ppm}$ could be assigned to bridging carbon atom of imidazothiazole ring. Other signals appeared in aromatic region accounting for the carbon atoms of both phenyl rings including equivalent ones. Further, formation of the compound $\mathbf{3 a}$ was strongly appended by mass spectrum LCMS with ion peak $358.2\left(\mathrm{M}^{+}-1\right)$ corresponding to its mass of 359.2. The physico-chemical characterization, elemental analysis and spectral characterization of these new derivatives are given in Tables 1 and 2 respectively.

In this series, para position of the benzothiazole amine was substituted with bromo and sulphonamide groups respectively. Further, these scaffolds were derivatized with variably substituted phenacyl bromides. The selection of bromo substitution was based on the pharmacological effect of halogen substitution in cancer chemotherapy. The role of halogen atoms in the drug development process mainly depended on the binding efficiency to form drug-target complexes due to steric effects. The bulky bromo group can adequately sit on binding site through halogen bonding. Of late it was understood that not only the steric effect but also other related complex interactions were the basis for the stability of protein-ligand complexes [11]. In an earlier study the poly brominated 4,5,6,7-tetrabromo- $1 \mathrm{H}$-benzotriazole was found to be potent and selective CK2 inhibitor and thus considered as reference compound for the bromo derivatives. Hence in this experiment the bromo substitution was selected to achieve better anticancer activity [12]. However, as the sulphonamide group was a proven pharmacophore, so it was selected for better radiosensitization.

\subsection{3-(4,5-Dimethylthiazol-2-yl)-2,5-diphenyltetra- zolium bromide assay (MTT) assay}

The formation of purple colored formazan in MTT assay was catalyzed by mitochondrial succinate dehydrogenase. The proliferating cells reduce MTT to MTTformazan complex due to mitochondrial respiration. The formation of this dye indicated the cell viability which was directly proportional to the optical density of complex. The $I C_{50}$ value was calculated by probit analysis (Fig. 1 and Table 3).

The cell viability (MTT) assay for compounds $\mathbf{3 a} \mathbf{a}-\mathbf{h}$ was been performed against Hep G2 cell line and the results are reported in Fig. 1. The newly synthesized compounds exhibited moderate $I C_{50}$ values ranged between 0.097 to $0.162 \mu \mathrm{M}$. The compound $\mathbf{3 f}$ emerged as the most active with $\mathrm{IC}_{50}$ value of $0.097 \mu \mathrm{M}$. As per the result, the compounds derived from bromo thiazole amine were less active compared to compounds derived from sulphonamide precursor. This can be visualized from Table 3 in which compounds $\mathbf{3 a}, \mathbf{3} \mathbf{b}$ and $\mathbf{3} \mathbf{c}$ showed higher $\mathrm{IC}_{50}$ values compared to compounds $\mathbf{3} \mathbf{h}, \mathbf{3 g}$ and $\mathbf{3 f}$ (sulfonamide substituted derivatives). Among the analyzed compounds two derivatives $\mathbf{3 f}$ (sulfonamide along with fluorine) and $\mathbf{3 g}$ (sulfonamide and methyl groups) at para positions on either side of the phenyl rings turned to be more potent ones. The presence of fluorine in a compound influences its cell permeability by acting as more lipophilic than hydrogen substituted compounds. The presence of fluorine makes the molecule an effective ligand to bind to the cellular targets. Likewise, the methyl group as substituent also plays crucial role in deciding the ADME property of a molecule, the methyl group can substantially boost the biological activity [13].

\subsection{Comet assay}

The compounds $\mathbf{3 f}, \mathbf{3 g}$ and $\mathbf{3 h}$ had low $I C_{50}$ values and appeared to be effective, hence further taken for
Table 1 Results of physical characterization and elemental analysis

\begin{tabular}{lllllll}
\hline Compounds & Formula & \multicolumn{2}{l}{ Calculated } & & Melting point $\left({ }^{\circ} \mathrm{C}\right)$ & Yield (\%) \\
\cline { 2 - 5 } & & $\mathrm{C}$ & $\mathrm{H}$ & $\mathrm{N}$ & \\
\hline $\mathbf{3 a}$ & $\mathrm{C}_{16} \mathrm{H}_{11} \mathrm{BrN}_{2} \mathrm{OS}$ & 53.35 & 3.02 & 7.75 & $214-216$ & 75 \\
$\mathbf{3 b}$ & $\mathrm{C}_{16} \mathrm{H}_{11} \mathrm{BrN}_{2} \mathrm{~S}$ & 55.89 & 3.20 & 8.10 & $204-207$ & 77 \\
$\mathbf{3 c}$ & $\mathrm{C}_{15} \mathrm{H}_{8} \mathrm{BrFN}_{2} \mathrm{~S}$ & 51.80 & 2.28 & 8.01 & $221-224$ & 75 \\
$\mathbf{3 d}$ & $\mathrm{C}_{15} \mathrm{H}_{8} \mathrm{BrN}_{3} \mathrm{O}_{2} \mathrm{~S}$ & 48.21 & 2.11 & 11.18 & $230-232$ & 74 \\
$\mathbf{3 e}$ & $\mathrm{C}_{15} \mathrm{H}_{10} \mathrm{~N}_{4} \mathrm{O}_{4} \mathrm{~S}_{2}$ & 48.12 & 2.58 & 14.92 & $>330$ & 72 \\
$\mathbf{3 f}$ & $\mathrm{C}_{15} \mathrm{H}_{10} \mathrm{FN}_{3} \mathrm{O}_{2} \mathrm{~S}_{2}$ & 51.82 & 2.85 & 12.05 & $256-258$ & 74 \\
$\mathbf{3 g}$ & $\mathrm{C}_{16} \mathrm{H}_{13} \mathrm{~N}_{3} \mathrm{O}_{2} \mathrm{~S}_{2}$ & 55.92 & 3.78 & 12.20 & $300-302$ & 75 \\
$\mathbf{3 h}$ & $\mathrm{C}_{16} \mathrm{H}_{13} \mathrm{~N}_{3} \mathrm{O}_{3} \mathrm{~S}_{2}$ & 53.70 & 3.61 & 11.62 & $266-268$ & 71 \\
\hline
\end{tabular}


Table 2 Results of spectral characterization

3a. 7-bromo-2-(4-methoxyphenyl)imidazo[2,1-b][1,3]benzothiazole

Spectral data

FT-IR, v cm ${ }^{-1}: 1683(-\mathrm{C}=\mathrm{N}), 1246(-\mathrm{C}-\mathrm{O}), 694(-\mathrm{C}-\mathrm{S}), 518$ (-C-Br). ${ }^{1} \mathrm{H}$ NMR (DMSO-d $\left.{ }_{6}, 400 \mathrm{MHz}\right), \delta \mathrm{ppm}: 3.79\left(\mathrm{~s}, 3 \mathrm{H},-\mathrm{OCH}_{3}\right), 7.01(\mathrm{~d}, 2 \mathrm{H}$, $\mathrm{J}=8 \mathrm{~Hz}, \mathrm{Ar}-\mathrm{H}), 7.78(\mathrm{~d}, 2 \mathrm{H}, \mathrm{J}=8 \mathrm{~Hz}, \mathrm{Ar}-\mathrm{H}), 7.91(\mathrm{~d}, 1 \mathrm{H}, \mathrm{J}=8 \mathrm{~Hz}, \mathrm{Ar}-\mathrm{H})$, $7.96(\mathrm{~d}, 1 \mathrm{H}, \mathrm{J}=8 \mathrm{~Hz}, \mathrm{Ar}-\mathrm{H}), 8.34(\mathrm{~s}, 1 \mathrm{H}, \mathrm{Ar}-\mathrm{H}), 8.65(\mathrm{~s}, 1 \mathrm{H}$, Imidazole-H).

${ }^{13} \mathrm{C}$ (DMSO-d $\left.{ }_{6}, 100 \mathrm{MHz}\right): \delta$ ppm: 56.0, 75.4, 113.6, 114.8, 115.7, 123.0, 123.3, 125.6, 127.9, 128.0, 129.4, 137.9, 143.2, 159.7, 161.0, 193.4. LCMS (ESI-MS): $\mathrm{m} / \mathrm{z} 358.2\left(\mathrm{M}^{+}-1\right)$.

3b. 7-bromo-2-(4-methylphenyl)imidazo[2,1-b][1,3]benzothiazole

FT-IR, $v \mathrm{~cm}^{-1}: 1635$ (-C=N), 1201 (-C-C), 692 (-C-S), 501 (-C-Br). ${ }^{1} \mathrm{H}$ NMR (DMSO- $\left.\mathrm{d}_{6}, 400 \mathrm{MHz}\right), \delta \mathrm{ppm}: 2.33\left(\mathrm{~s}, 3 \mathrm{H},-\mathrm{CH}_{3}\right), 7.23(\mathrm{~d}$, $2 \mathrm{H}, \mathrm{J}=7.6 \mathrm{~Hz}, \mathrm{Ar}-\mathrm{H}), 7.76(\mathrm{~d}, 2 \mathrm{H}, \mathrm{J}=6.8 \mathrm{~Hz}, \mathrm{Ar}-\mathrm{H}), 7.73(\mathrm{br} \mathrm{s}, 1 \mathrm{H}, \mathrm{Ar}-\mathrm{H})$ $7.92(\mathrm{~d}, 1 \mathrm{H}, \mathrm{J}=8.4 \mathrm{~Hz}, \operatorname{Ar}-\mathrm{H}), 8.35(\mathrm{~s}, 1 \mathrm{H}, \mathrm{Ar}-\mathrm{H}), 8.73(\mathrm{~s}, 1 \mathrm{H}$, ImidazoleH).

${ }^{13} \mathrm{C}$ (DMSO- $\left.\mathrm{d}_{6}, 100 \mathrm{MHz}\right) \delta \mathrm{ppm}: 21.1,113.6,115.2,123.0,123.3,127.9$, $128.0,129.4,132.4,137.2,137.9,143.2,159.7$. LCMS (ESI-MS): $\mathrm{m} / \mathrm{z}$ $342.5\left(\mathrm{M}^{+}-1\right)$.

3c. 7-bromo-2-(4-fluorophenyl)imidazo[2,1-b][1,3]benzothiazole

FT-IR, $v \mathrm{~cm}^{-1}: 1646(-\mathrm{C}=\mathrm{N}), 1251(-\mathrm{C}-\mathrm{F}), 698(-\mathrm{C}-\mathrm{Br})$

${ }^{1} \mathrm{H}$ NMR (DMSO-d $\left.\mathrm{d}_{6}, 400 \mathrm{MHz}\right), \delta \mathrm{ppm}: 7.26(\mathrm{~d}, 2 \mathrm{H}, J=8.4 \mathrm{~Hz}, \mathrm{Ar}-\mathrm{H}), 7.75$ (d, $1 \mathrm{H}, \mathrm{J}=8.4 \mathrm{~Hz}, \mathrm{Ar}-\mathrm{H}), 7.86$ (br s, 3H, Ar-H), 8.35 (s, 1H, Ar-H), 8.76 (s, $1 \mathrm{H}$, Imidazole-H).

${ }^{13} \mathrm{C}$ (DMSO-d $\left.\mathrm{d}_{6}, 100 \mathrm{MHz}\right) \delta \mathrm{ppm:}$ 115.2, 116.2, 116.4, 117.8 $\left(d,{ }^{1} J C_{F}=160 \mathrm{~Hz}\right), 122.9\left(d,{ }^{1} J C_{F}=264 \mathrm{~Hz}\right), 128.94\left(d^{1}{ }^{1} J C_{F}=12 \mathrm{~Hz}\right)$, 129.8, 138.0, 143.2, 147.3, 159.7, 162.0, 164.1. LCMS (ESI-MS): $\mathrm{m} / \mathrm{z}$ $346.3\left(M^{+}+1\right)$.

3d. 7-bromo-2-(4-nitrophenyl)imidazo[2,1-b][1,3]benzothiazole

3e. 2-(4-nitrophenyl)imidazo[2,1-b][1,3]benzothiazole-7-sulfonamide

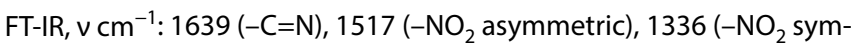
metric), $624(-\mathrm{C}-\mathrm{Br})$.

${ }^{1} \mathrm{H}$ NMR (DMSO-d $\left.\mathrm{d}_{6}, 400 \mathrm{MHz}\right), \delta \mathrm{ppm}: 7.75(\mathrm{~d}, 1 \mathrm{H}, \mathrm{J}=8.4 \mathrm{~Hz}, \mathrm{Ar}-\mathrm{H})$, $7.94(\mathrm{~d}, 1 \mathrm{H}, \mathrm{J}=8.4 \mathrm{~Hz}, \mathrm{Ar}-\mathrm{H}), 8.07$ (d, $2 \mathrm{H}, \mathrm{J}=8.4 \mathrm{~Hz}, \mathrm{Ar}-\mathrm{H}), 8.29(\mathrm{~d}, 2 \mathrm{H}$, $\mathrm{J}=8.4 \mathrm{~Hz}, \mathrm{Ar}-\mathrm{H}), 8.36(\mathrm{~s}, 1 \mathrm{H}, \mathrm{Ar}-\mathrm{H}), 9.06(\mathrm{~s}, 1 \mathrm{H}$, Imidazole-H).

${ }^{13} \mathrm{C}$ (DMSO-d $\left.{ }_{6}, 100 \mathrm{MHz}\right) \delta$ ppm: 113.6, 115.2, 123.0, 123.3, 125.0, $126.8,127.9,129.4,137.1,137.9,143.2,145.8,159.7$. LCMS (ESI-MS): $\mathrm{m} / \mathrm{z} 375.2\left(\mathrm{M}^{+}+1\right)$.

FT-IR, $v \mathrm{~cm}^{-1}: 3259\left(-\mathrm{NH}_{2}\right), 1639(-\mathrm{C}=\mathrm{N}), 1518\left(-\mathrm{NO}_{2}\right.$ asymmetric), 1317 ( $-\mathrm{NO}_{2}$ symmetric), $1159(-\mathrm{S}=\mathrm{O})$.

${ }^{1} \mathrm{H}$ NMR (DMSO- $d_{6}, 500 \mathrm{MHz}$ ): $\delta$ ppm: 7.13 (s, 1H, imidazole-H), 7.47 (s, $\left.2 \mathrm{H}, \mathrm{SO}_{2} \mathrm{NH}_{2}\right), 7.90(\mathrm{~d}, 2 \mathrm{H}, \mathrm{J}=7.5, \mathrm{Ar}-\mathrm{H}), 8.14(\mathrm{~d}, 1 \mathrm{H}, J=7.5 \mathrm{~Hz}, \mathrm{Ar}-\mathrm{H})$, $8.30(\mathrm{~d}, 2 \mathrm{H}, J=7.5 \mathrm{~Hz}, \operatorname{Ar}-\mathrm{H}), 8.43(\mathrm{~d}, 1 \mathrm{H}, J=7.5 \mathrm{~Hz}, \operatorname{Ar}-\mathrm{H}), 8.66(\mathrm{~s}, 1 \mathrm{H}$, $\mathrm{Ar}-\mathrm{H})$.

${ }^{13} \mathrm{C}$ NMR (DMSO- $\left.d_{6}, 100 \mathrm{MHz}\right) \delta \mathrm{ppm:} 115.2,117.6,118.0,122.6,123.2$, 125.0, 126.8, 137.1, 138.0, 143.2, 145.8, 147.3, 159.7; LCMS (ESI-MS): $\mathrm{m} / \mathrm{z} 375.06\left(\mathrm{M}^{+}+1\right)$.

3f. 2-(4-fluorophenyl)imidazo[2,1-b][1,3]benzothiazole-7-sulfonamide

FT-IR, $v \mathrm{~cm}^{-1}: 3288\left(-\mathrm{NH}_{2}\right), 1631(-\mathrm{C}=\mathrm{N}), 1325(-\mathrm{C}-\mathrm{F}), 1159(-\mathrm{S}=\mathrm{O})$. ${ }^{1} \mathrm{H}$ NMR (DMSO- $\left.d_{6}, 500 \mathrm{MHz}\right) \delta \mathrm{ppm}: \delta 7.15$ (dd, $3 \mathrm{H}, J=8 \mathrm{~Hz}, J=10 \mathrm{~Hz}$, Ar-H), 7.63 (dd, $2 \mathrm{H}, J=6 \mathrm{~Hz}, J=7.5 \mathrm{~Hz}, \mathrm{Ar}-\mathrm{H}), 7.84\left(\mathrm{~s}, 2 \mathrm{H}, \mathrm{SO}_{2} \mathrm{NH}_{2}\right)$, $8.14(\mathrm{dd}, 1 \mathrm{H}, J=7.5 \mathrm{~Hz}, J=7.5 \mathrm{~Hz}, \mathrm{Ar}-\mathrm{H}), 8.43(\mathrm{~d}, 1 \mathrm{H}, J=7.5 \mathrm{~Hz}, \mathrm{Ar}-\mathrm{H})$, $8.67(\mathrm{~s}, 1 \mathrm{H}$, imidazole-H).

${ }^{13} \mathrm{C}$ NMR (DMSO- $\left.d_{6}, 100 \mathrm{MHz}\right) \delta \mathrm{ppm:} 113.6,115.2,116.3$ (d, $\left.{ }^{1} J C_{F}=88 \mathrm{~Hz}\right), 123.0,123.3,127.93,129.6\left(\mathrm{~d},{ }^{1} J C_{\mathrm{F}}=124 \mathrm{~Hz}\right), 129.8$, 137.9, 143.25, 159.78, 162.0, 164.1; LCMS (ESI-MS): $m / z 348.06$ $\left(\mathrm{M}^{+}+1\right)$.

3g. 2-(4-methylphenyl)imidazo[2,1-b][1,3]benzothiazole-7-sulfonamide

FT-IR, v cm ${ }^{-1}: 3246\left(-\mathrm{NH}_{2}\right), 1652(-\mathrm{C}=\mathrm{N}), 1151(-\mathrm{S}=\mathrm{O})$.

${ }^{1} \mathrm{H}$ NMR (DMSO- $\left.d_{6}, 500 \mathrm{MHz}\right) \delta \mathrm{ppm}: \delta 2.34\left(\mathrm{~s}, 3 \mathrm{H},-\mathrm{CH}_{3}\right), 7.13(\mathrm{~s}$, $1 \mathrm{H}$, imidazole-H), $7.29(\mathrm{~d}, 2 \mathrm{H}, \mathrm{J}=7.5 \mathrm{~Hz}, \mathrm{Ar}-\mathrm{H}), 7.59(\mathrm{~d}, 2 \mathrm{H}, J=7 \mathrm{~Hz}$, Ar), $7.69\left(\mathrm{~s}, 2 \mathrm{H}, \mathrm{SO}_{2} \mathrm{NH}_{2}\right), 8.13(\mathrm{~d}, 1 \mathrm{H}, J=7.5 \mathrm{~Hz}, \mathrm{Ar}-\mathrm{H}), 8.43(\mathrm{~d}, 1 \mathrm{H}$, $J=7.5 \mathrm{~Hz}, \mathrm{Ar}-\mathrm{H}), 8.67(\mathrm{~s}, 1 \mathrm{H}, \mathrm{Ar}-\mathrm{H})$.

${ }^{13} \mathrm{C}$ NMR $\left(75.5 \mathrm{MHz}\right.$, DMSO- $d_{6}$ ) $\delta$ ppm: $21.1,115.2,117.6,118.0,112.6$, $123.2,128.0,129.4,132.4,137.2,138.0,143.2,147.3,159.2$; LCMS (ESI-MS): $m / z 407.99$ 
Table 2 (continued)

\begin{tabular}{|c|c|}
\hline Compound & Spectral data \\
\hline $\begin{array}{l}\text { 3h. 2-(4-methoxyphenyl)imidazo[2,1-b][1,3]benzothiazole-7-sulfona- } \\
\text { mide }\end{array}$ & 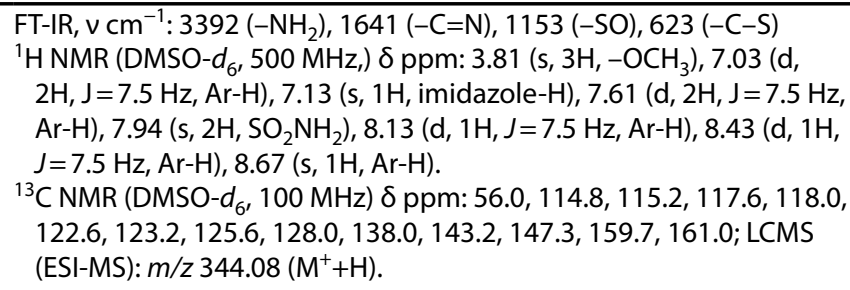 \\
\hline
\end{tabular}

Fig. 1 Cell viability of Hep G2 cells as determined by MTT assay of $\mathbf{3 a - h}$

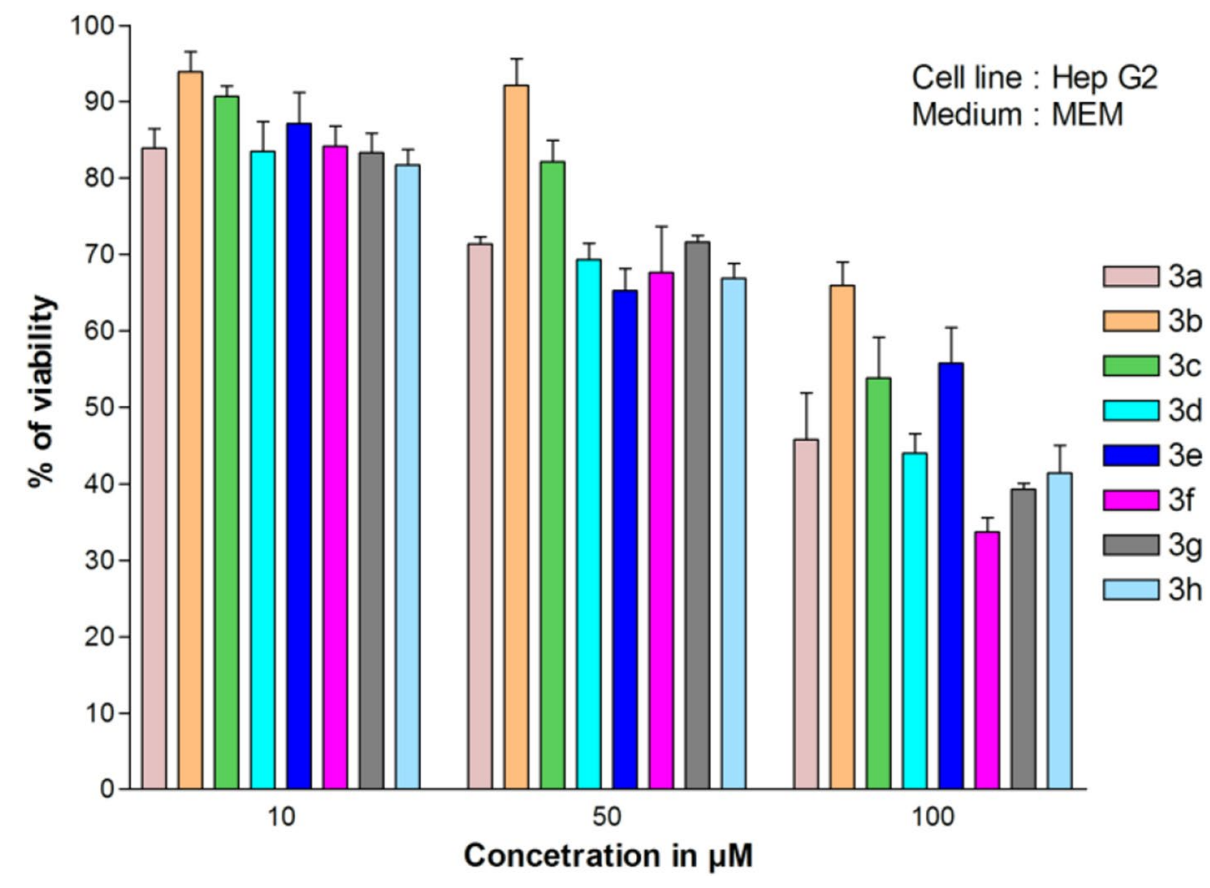

Table $3 \mathrm{IC}_{50}$ value of compounds $\mathbf{3 a}-\mathbf{h}$ by MTT assay in $1 \mu \mathrm{g} / \mu \mathrm{l}$ concentration

\begin{tabular}{llll}
\hline Compound & $\mathrm{R}$ & $\mathrm{R}^{\mathrm{l}}$ & $\mathrm{IC}$ in $\mu \mathrm{M}$ \\
\hline 3a & $-\mathrm{Br}$ & $-\mathrm{OCH}_{3}$ & $0.122 \pm 0.28$ \\
3b & $-\mathrm{Br}$ & $-\mathrm{CH}_{3}$ & $0.162 \pm 0.15$ \\
3c & $-\mathrm{Br}$ & $-\mathrm{F}$ & $0.154 \pm 0.22$ \\
3d & $-\mathrm{Br}$ & $-\mathrm{NO}_{2}$ & $0.117 \pm 0.19$ \\
3e & $-\mathrm{SO}_{2} \mathrm{NH}_{2}$ & $-\mathrm{NO}_{2}$ & $0.148 \pm 0.24$ \\
3f & $-\mathrm{SO}_{2} \mathrm{NH}_{2}$ & $-\mathrm{F}$ & $0.097 \pm 0.29$ \\
3g & $-\mathrm{SO}_{2} \mathrm{NH}_{2}$ & $-\mathrm{CH}_{3}$ & $0.114 \pm 0.35$ \\
3h & $-\mathrm{SO}_{2} \mathrm{NH}_{2}$ & $-\mathrm{OCH}_{3}$ & $0.115 \pm 0.32$ \\
\hline
\end{tabular}

radiosensitization study against Hep G2 cell line. The comet assay for all the three compounds were performed at $0.054 \mu \mathrm{M}$ (half of $\mathrm{IC}_{50}$ ) drug concentration irradiating with $4 \mathrm{~Gy} \Upsilon$-ray (Figs. 2, 3 and 4). The study showed that comet formed from $\mathbf{3 h}$ had long tail formation $(27.34 \pm 0.91)$ compared to $\mathbf{3 f}(24.58 \pm 0.48)$ and $\mathbf{3 g}$

SN Applied Sciences

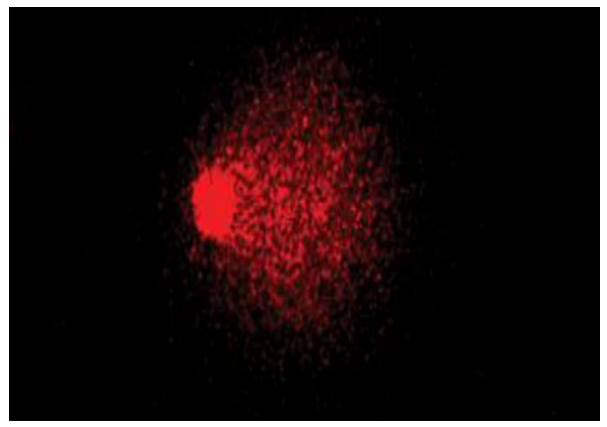

Fig. 2 Comet assay of $\mathbf{3 f}$

(16.86 \pm 1.08$)$ (Table 4), shown to be effective among tested compounds as DNA damaging agent. 


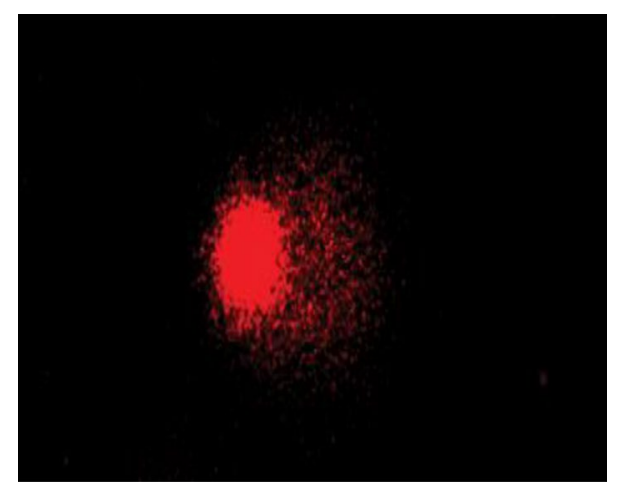

Fig. 3 Comet assay of $\mathbf{3 g}$

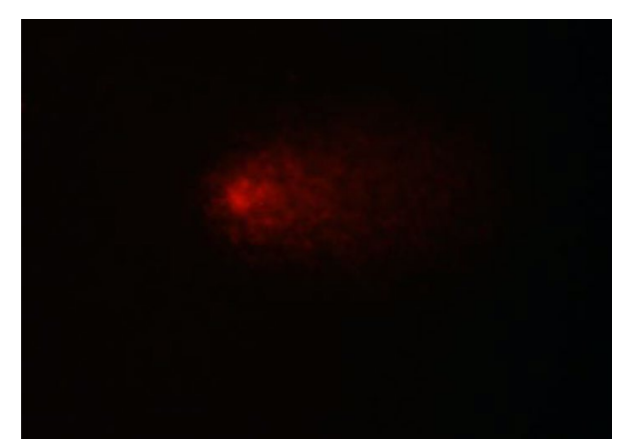

Table 4 Determination of apoptosis by comet assay

\begin{tabular}{ll}
\hline Compound & $\begin{array}{l}\text { Percentage } \\
\text { DNA dam- } \\
\text { age }\end{array}$ \\
\hline $\mathbf{3 f}$ & $24.58 \pm 0.48$ \\
$\mathbf{3 g}$ & $16.86 \pm 1.08$ \\
$\mathbf{3 h}$ & $27.34 \pm 0.91$ \\
\hline
\end{tabular}

Table 5 Cell cytotoxic effect of compounds

\begin{tabular}{|c|c|c|c|c|}
\hline \multirow[t]{3}{*}{ Compounds } & \multicolumn{2}{|l|}{ A375 } & \multicolumn{2}{|l|}{ B16F10 } \\
\hline & \multicolumn{4}{|l|}{$\mathrm{IC}_{50}(\mu \mathrm{M})$} \\
\hline & Parental & Resistant & Parental & Resistant \\
\hline $3 \mathbf{a}$ & 0.123 & $0.105 \pm 0.09$ & 0.071 & $0.126 \pm 0.17$ \\
\hline $3 \mathbf{b}$ & 0.163 & $0.296 \pm 0.15$ & 0.035 & $0.154 \pm 0.1$ \\
\hline $3 c$ & 0.046 & $0.047 \pm 0.13$ & 0.033 & $0.102 \pm 0.21$ \\
\hline 3d & 0.236 & 0.216 & 0.231 & 0.244 \\
\hline $3 e$ & 0.504 & 0.563 & 0.533 & 0.353 \\
\hline $3 f$ & 0.917 & 0.183 & 0.168 & 0.217 \\
\hline $\mathbf{3 g}$ & 0.927 & 0.185 & 0.170 & 0.219 \\
\hline $3 \mathbf{h}$ & 0.885 & 0.177 & 0.163 & 0.209 \\
\hline
\end{tabular}

Fig. 4 Comet assay of $\mathbf{3 h}$

Fig. 5 MTT cell viability assay of melanoma cells treated with $3 c$ along with irradiation

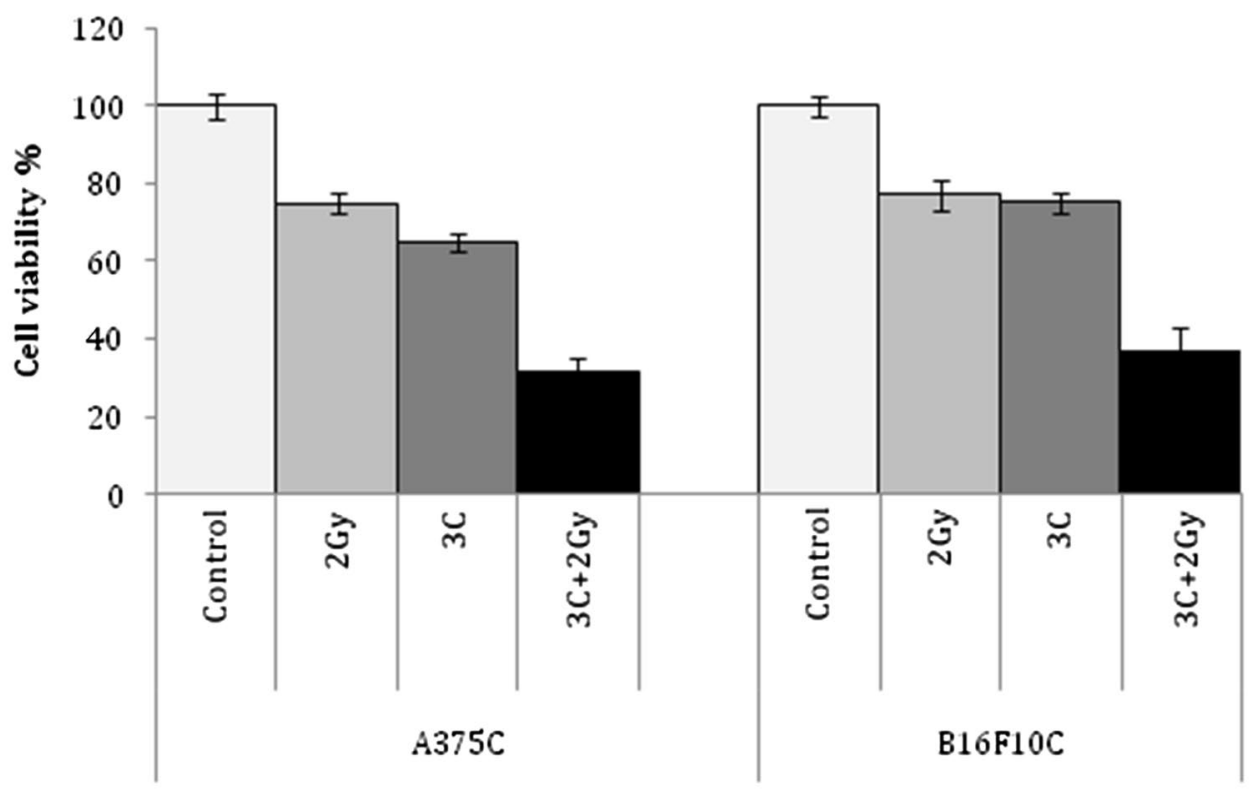




\subsection{Radiosensitizing study on melanoma cells}

Using dose-response curves for two parental melanoma cell lines, $I C_{50}$ values of all the compounds were calculated and results are presented in Table 5. Among the seven tested compounds, $3 \mathrm{c}$ exhibited the best cytotoxic activity against all parental ( $\mathrm{A} 375 \mathrm{C}$ and $\mathrm{B} 16 \mathrm{~F} 10 \mathrm{C})$ and drug resistant (A375R and B16F10R) melanoma cell lines. All the other compounds afforded moderate anticancer activity against cancer cell lines.

The parental and drug-resistant cells of $\mathrm{A} 375$ and $\mathrm{B} 16 \mathrm{~F} 10$ cells were pretreated with an $\mathrm{IC}_{50}$ concentration of $3 \mathrm{c}$ for $24 \mathrm{~h}$ and irradiated with $2.0 \mathrm{~Gy} \mathrm{Y}$-radiation. The cell viability in melanoma cells with irradiation at $2.0 \mathrm{~Gy}$ and 3c, was $20-38 \%$ respectively (Fig. 2). Treatment with both $\mathbf{3 c}$ and irradiation showed synergistic effects, i.e., cell viability was less than cell treated individually or untreated. The cell viability was significantly reduced $(p<0.001)$ in both cell lines but A375 cells were found to be more sensitive. The concentration of melanin was estimated by the differences in the absorbance at $470 \mathrm{~nm}$. The pretreatment with $\mathbf{3 c}$ had shown to decrease in absorbance at $470 \mathrm{~nm}$ for both cell lines compared to untreated cells (Fig. 5).

\section{Conclusion}

A series of bromo and sulphonamide substituted benzothiazole derivatives (3a-h) were synthesized and characterized by spectroscopic techniques. The new molecules were subjected to antiproliferative activity on Hep G2 and two parental melanoma cell lines. Among the synthesized compounds $\mathbf{3 f}$ (sulfonamide along with fluorine) and $\mathbf{3 g}$ (sulfonamide and methyl groups) at para positions on either side of the phenyl rings appear to be cytotoxic agents with $\mathrm{IC}_{50} 0.097$ and $0.114 \mu \mathrm{M}$ respectively for Hep $\mathrm{G} 2$ cell line. The radiosensitizing effect of these two compounds at $0.054 \mu \mathrm{M}$ (half of $\mathrm{IC}_{50}$ ) on hypoxic HepG2 cells was evident by comet assay. The concomitant effect of these two compounds on cytotoxic activity and radiosensitization on HepG2 cells seem to be promising. While 3c (bromo substitution along with fluorine) was potent against two parental melanoma cell lines, with $\mathrm{IC}_{50} 0.046$ and $0.052 \mu \mathrm{M}$ respectively. When combined with $2 \mathrm{~Gy}$ $\Upsilon$-radiation, $3 \mathrm{c}$ seemed to be more potent on melanoma cells with $30-40 \%$ viability. Hence, these molecules which were synthesized by adopting simple procedures could be potential drug candidates to be exploited for radiosensitization during radiation associated chemotherapy.

\section{Compliance with ethical standards}

Conflict of interest The corresponding author states that there is no conflict of interest.

\section{References}

1. Jayam R, Vijay KB, Venkata SK, Uday SR, Venkata S (2014) Radiosensitizers, radioprotectors, and radiation mitigators. Indian J Dent Res 25:83-90. https://doi.org/10.4103/0970-9290.131142

2. David RR, Daphne A (2013) Molecular targets and mechanisms of radiosensitization using DNA damage response pathways. Future Oncol 9(2):219-233. https://doi.org/10.2217/fon.12.185

3. Ozensoy GO, Capasso C, Supuran CT (2016) A magnificent enzyme superfamily: Carbonic anhydrases, their purification and characterization. J Enzyme Inhib Med Chem 31:689-694. https://doi.org/10.3109/14756366.2015.1059333

4. Elena A, Jessica R, Silvia P, Francesca B, Anna L, Fabrizio C, Claudiu TS, Lido C (2019) The carbonic anhydrase IX inhibitor SLC-0111 sensitises cancer cells to conventional chemotherapy. J Enzyme Inhib Med Chem 34(1):117-123. https://doi.org/10.1080/14756 366.2018.1532419

5. Cecilia AH, Pierre JM, Stuart RM, Harvey S, John MS, Robert LS, Michael FS, Kenneth LS (1994) 3-Substituted thieno[2,3-b][l,4] thiazine-6-sulfonamides. A novel class of topically active carbonic anhydrase inhibitors. Med Chem 37:240-247. https://doi. org/10.1021/jm00028a006

6. Supuran CT (2003) Indisulam: an anticancer sulfonamide in clinical development. Expert Opin Investig Drugs 12(2):283-287. https://doi.org/10.1517/13543784.12.2.283

7. Kumbhare RM, Vijay Kumar K, Janaki RM, Dadmal T, Pushpavalli SN, Mukhopadhyay D, Divya B, Anjana DT, Kosurkar U, PalBhadra M (2011) Synthesis and biological evaluation of novel Mannich bases of 2-arylimidazo[2,1-b]benzothiazoles as potential anti-cancer agents. Eur J Med Chem 46:4258-4266. https:// doi.org/10.1016/j.ejmech.2011.06.031

8. Swetha KM, Zhen-Zhen L, Vijaya KK, Rammohan RYB, Balaraju T, Vijai KRT, Cheng-He Z (2018) Azoalkyl ether imidazo[2,1-b] benzothiazoles as potentially antimicrobial agents with novel structural skeleton. Bioorg Med Chem Lett 28:2426-2431. https ://doi.org/10.1016/j.bmcl.2018.06.016

9. Chandak N, Jitender KB, Rajnesh KS (2012) Inhibitors of apoptosis in testicular germ cells: Synthesis and biological evaluation of some novel IBTs bearing sulfonamide moiety. Eur J Med 59:203-208. https://doi.org/10.1016/j.ejmech.2012.11.015

10. Bhuvanesh SK, Vinitha RP, Santosh KB, Hiriyur MS (2019) HDAC2 inhibitor valproic acid increases radiation sensitivity of drugresistant melanoma cells. Med Sci (Basel) 7(3):51. https://doi. org/10.3390/medsci7030051

11. Hernandes MZ, Cavalcanti SMT, Moreira DRM, de Azevedo Junior WF, Leite ACL (2010) Halogen atoms in the modern medicinal chemistry: hints for the drug design. Curr Drug Targets 11(3):303-314. https://doi.org/10.2174/138945010790711996

12. Baldrighi M, Metrangolo P, Pilati T, Resnati G, Terraneo G (2017) Halogen and hydrogen bonding in multicomponent crystals of tetrabromo-1H-benzotriazole. Crystals 7(11):332. https://doi. org/10.3390/cryst7110332

13. Uwabagira N, Sarojini B, Poojary B (2018) N-(3-Chloro-2methylphenyl)-4-(4-fluorophenyl)-1,3-thiazol-2-amine. Molbank 2018(1):M975. https://doi.org/10.3390/m975

Publisher's Note Springer Nature remains neutral with regard to jurisdictional claims in published maps and institutional affiliations. 